\title{
BIOCHEMICAL CHANGES OF THE CHITIN-SYNTHESIS INHIBITOR, HEXAFLUMURON (CONSULT), SPINOSAD (TRACER) AND THEIR MIXTURE ON THE DESERT LOCUST, Schistocerca gregaria (FORSKAL)
}

\author{
Said, M. S. ${ }^{(1) ;}$ Th. A . Abdel-Fattah ${ }^{(1)} ;$ H. M. Sobhy ${ }^{(2)}$ and \\ W. Z. Azer ${ }^{(2)}$
}

(1) Department of Locust and Grasshoppers, Plant Protection Institute, Agricultural Research Center, Dokki, Giza, Egypt.

(2) Natural Resources Department, Institute of African Research and Studies, Cairo University, Egypt

\begin{abstract}
Laboratory experiments were carried out in an attempt to disclose the effect of a bio-insecticide (Spinosad), an IGR (consult) and their mixture at different concentrations (19ppm), (123ppm) and (9ppm of spinosad+52ppm of consult), respectively on one day old of the $5^{\text {th }}$ nymphal instar of the desert locust, Schistocerca gregaria (Forskal) by feeding technique.

Total proteins, lipids and cholesterol contents were determined after 2, 4 and 6 days of treatment with Spinosad (at $\mathrm{LC}_{50}$ value), consult(at $\mathrm{LC}_{50}$ value) and their mixture(at $\mathrm{LC}_{25}$ values). Total proteins, total lipids, total cholesterol, Highly significant decline were recorded in them by mixture.
\end{abstract}

Keywords: Schistocerca gregaria, haemolymph, biochemical changes, Spinosad, consult

\section{INTRODUCTION}

The desert locust, Schistocerca gregaria (Forskal) has been an important agricultural pest at least since biblical times. Although the ecology, physiology and behavior of this insect species have been well characterized, its bio-geographical origins and evolutionary history are more obscure. (Lovejoy, et al., 2006). The desert locust S. gregaria is an economically dangerous pest invading several countries in North Africa and West Asia (Hamadah, et al., 2013). Locust and grasshoppers have been some of the greatest agricultural pests since the beginning of civilization. They are the most voracious pests known capable of eating their own weight $(2-3 \mathrm{~g})$ of vegetation daily (Alomenu, 1998).

The use of chemical pesticides has been the main insect controlling approach during recent decades, but the widespread use of such chemicals has significant drawbacks, such as the development of strain resistance to insecticides (Garriga and Caballero, 2011).

Environmental issues arising from the standard use of chemical pesticides against locusts and grasshoppers include the impact on operators, other people, livestock and birds (Matteson, 1992). Other terrestrial vertebrates, aquatic organisms (e.g. fish) and terrestrial arthropods including the natural enemies of locusts and grasshoppers, as well as pollution issues, contamination of groundwater and wells and disposal of surplus pesticides 
stocks (Ritchie and Dobson, 1995). From this point of view, it is necessary to minimize the application of pesticides that considered as a main source of environmental pollution and use other compounds may proof as good alternative of insecticides. Among these compounds are the uses of Spinosad (El- Sheikh, 2012). and Chitin synthesis inhibitors which prevent the formation of chitin, a carbohydrate that is an important structural component of the insect's exoskeleton. When treated with one of these compounds, the insect grows normally until the time to molt. When the insect molts, the exoskeleton is not properly formed and it dies. Death may be quick, but in some insects it may take several days. As well as disrupting molting, chitin synthesis inhibitors can kill eggs by disrupting the normal development of the embryo e.g. consult (Thabit, et al., 2010). Therefore the present investigation aimed to study the biochemical changes of the chitin-synthesis inhibitor, hexaflumuron, spinosad and their mixture on $S$. gregaria.

\section{MATERIALS AND METHODS}

\section{Rearing of test insects}

Nymphal instars of the desert locust, Schistocerca gregaria Forskal (Orthoptera: Acrididae) one days after ecdysis were used in all experiments. The individuals were taken from the sock culture maintained for several generations at the Locust Research Section, Plant Protection Research Institute (PPRI), ARC, Dokki, Giza. The insects were reared in the laboratory according to (Robert et al., 2002)

\section{Pesticides}

Spinosad

Common Name: spinosad 22.5\% SC (Suspension Concentrate)

Trade Names: Tracer®

Chitin-synthesis inhibitor

Common name: Hexaflumuron 10\% EC (Emulsifiable Concentrate)

Trade name: Consult ${ }^{\circledR}$ (Bakr, et al., 2009)

3. Characterization of the haemolymph of the $5^{\text {th }}$ nymphal instar after treatment with Spinosad and consult

Samples collection and preparation

Fifth instar nymphs were taken for each experiment under laboratory conditions. Fifty treated nymphs were divided into five replications. Nymphs were kept in cages $(25 \times 25 \times 60 \mathrm{~cm})$ at $30 \pm 2{ }^{\circ} \mathrm{C}$ and $30-50 \% \mathrm{RH}$. with a fluorescent lamp as a light source. The control insects were placed in other cages under the same conditions in $16 \mathrm{~h}$ light and $8 \mathrm{~h}$ dark (Robert et al., 2002). Samples of the haemolymph were taken at different intervals of 2,4 , and 6 days after treatment.

The haemolymph was collected through a fine puncture in the hind leg membrane and transferred into clean dry centrifuge tubes. Few crystals of phenylthiourea were added to prevent melanization before analysis. A known volume of the collected haemolymph was centrifuged on $13000 \mathrm{rpm}$ to 15 min. to remove blood cells and pigments. Then the supernatant collected for analyses (El Gawhary, 1997). 
Determination of the total proteins by the method of Bradford (1976).

Determination of total lipids by the method of Knight et al. (1972).

Determination of total cholesterol by the enzymatic colourimetric method of Richmond (1973).

4. Calculations and data analysis:

Statistical analysis of results was statistically analyzed by analysis of variance (ANOVA) and the means were compared by L.S.D. test at 0.05 level, using SAS program (SAS, 1988).

\section{RESULTS}

1- Characterization of the haemolymph of the fifth nymphal instar of desert locust, S. gregaria after treated with consult, spinosad and their mixture

\section{Effect on total protein level:}

In this study, the biochemical effects of Spinosad (at $L C_{50}=19 \mathrm{ppm}$ ) and consult (at $\mathrm{LC}_{50}=123 \mathrm{ppm}$ ) and their mixture (at Spinosad $\mathrm{LC}_{25}=9 \mathrm{ppm}+$ consult $\mathrm{LC}_{25}=50 \mathrm{ppm}$ ) on haemolymph protein contents were evaluated. The experiments were carried out by treatment of 1 -day old nymphs.

Data in and Figure (1) showed that, the levels of haemolymph protein content were significantly and negatively deceased after 2, 4 and 6 days when the $5^{\text {th }}$ nymphal instar were treated during one day old with different concentrations of Consult, Spinosad and their mixture compounds comparing by control nymphs. This significant difference appeared between treatments and control through the application period. The haemolymph protein levels significantly decreased in treated nymphs after two days of treatment, these levels were $51,47.1$ and $44 \mathrm{mg} / \mathrm{ml}$ at different treatments; consult, Spinosad and their mixture, respectively compared with $53.3 \mathrm{mg} / \mathrm{ml}$ of untreated nymphs. Also, haemolymph protein levels deceased in treated nymphs after four days of treatment, these levels were $50.3,47.4$ and $42.1 \mathrm{mg} / \mathrm{ml}$ at different treatments; consult, Spinosad and their mixture respectively compared with $58.1 \mathrm{mg} / \mathrm{ml}$ of normal nymphs, also these levels were 48.7 , 45.7 and $40.7 \mathrm{mg} / \mathrm{ml}$ haemolymph compared with $55.6 \mathrm{mg} / \mathrm{ml}$ of normal nymphs after 6 days.

\section{Determination of total lipids:}

The effects of bio-insecticide, spinosad and IGR, consult with their $\mathrm{LC}_{50}$ values $19 \mathrm{ppm}$ and $123 \mathrm{ppm}$, respectively and their mixture at $\mathrm{LC}_{25}$ values 9ppm of Spinosad and $50 \mathrm{ppm}$ of consult, after 2, 4 and 6 days of treatment are summarized in Table (8) and Figure (2). There were significant differences of total lipid contents at all treatments comparing with control.The mixture show highly significant decrease in the total lipid content, $4.57,4.04$ and $3.57 \mathrm{mg} / \mathrm{ml}$ haemolymph after 2,4 and 6 days of treatment respectively, compared to control $7.3,7.4$ and $6.95 \mathrm{mg} / \mathrm{ml}$ haemolymph.

Determination of cholesterol levels

Data and Figure (3) revealed that Treatment nymphs of the desert locust, S. gregaria with19ppm, 123ppm and $(9 \mathrm{ppm}+50 \mathrm{ppm})$ of Spinosad, consult and their mixture respectively, caused significant differences between 
treated and untreated nymphs during $2^{\text {nd }}, 4^{\text {th }}$ and $6^{\text {th }}$ days of application. Cholesterol contents were declined in all treatments. Highly significant

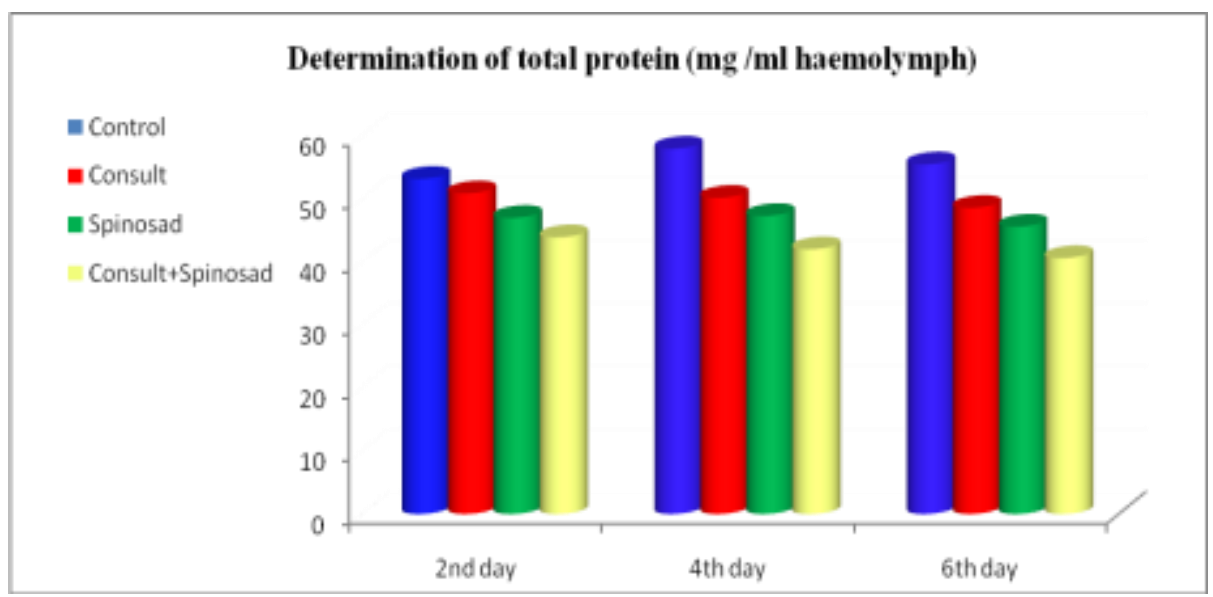

decline were recorded in cholesterol content at nymphs treated with mixture.

Figure (1). Determination of total protein ( $\mathrm{mg} \% / 100 \mathrm{ml}$ haemolymph) of the $5^{\text {th }}$ nymphal instar of desert locust, $S$. gregaria after treated with spinosad, consult and their mixture.

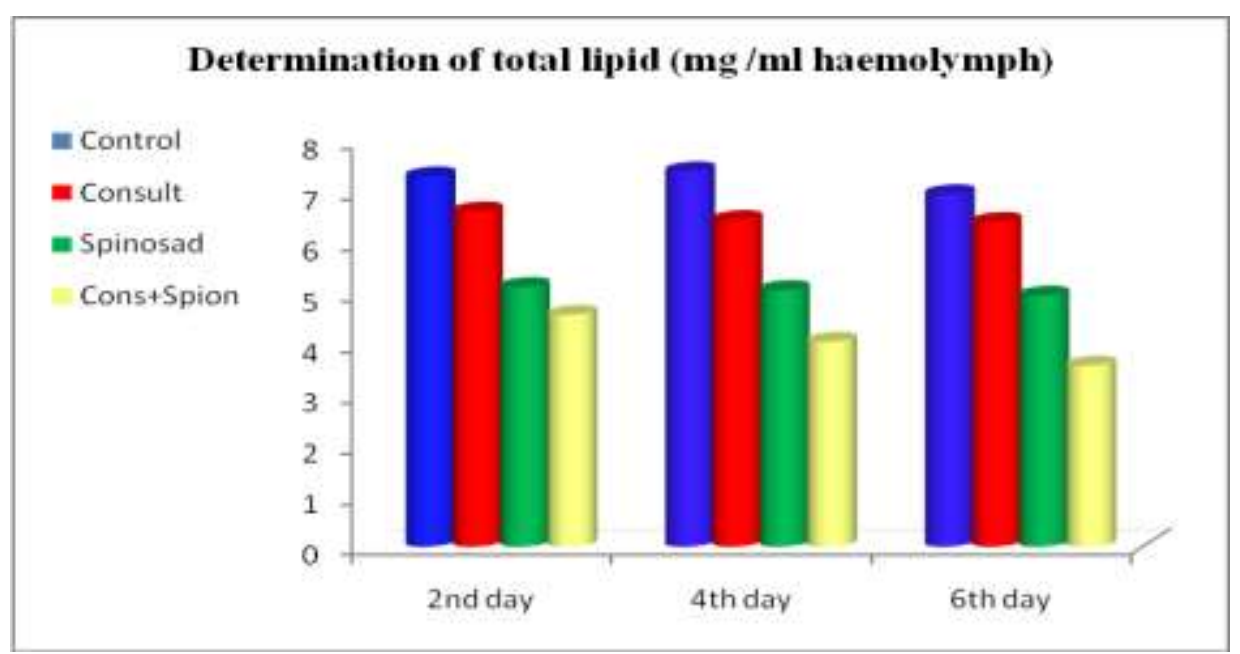

Figure (2). Determination of total lipid ( $\mathrm{mg} \% / 100 \mathrm{ml}$ haemolymph) of the $5^{\text {th }}$ nymphal instar of desert locust, $S$. gregaria after treated with spinosad, consult and their mixture. 


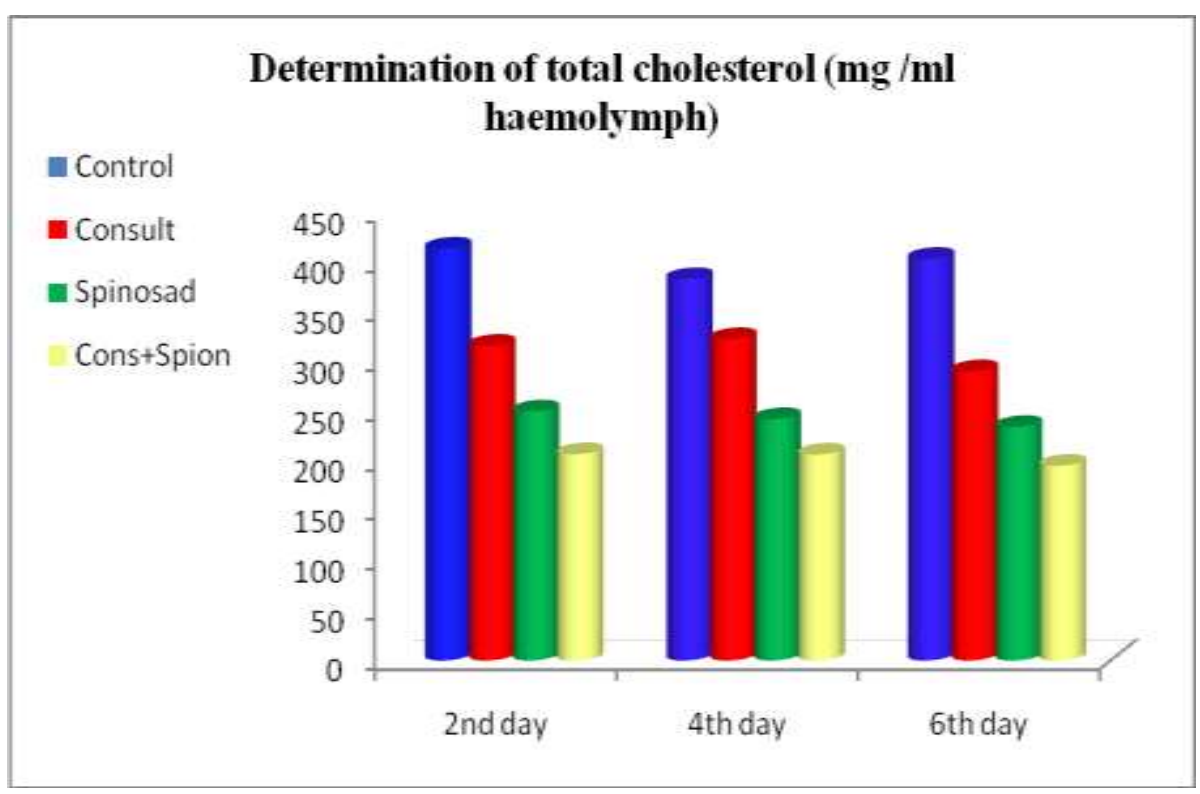

Figure (3). Determination of total cholesterol $(\mathrm{mg} / \mathrm{ml}$ haemolymph) of the $5^{\text {th }}$ nymphal instar of desert locust, $S$. gregaria after treated with spinosad, consult and their mixture.

\section{DISCUSSION}

\section{Determination of total protein:}

The daily activities of an insect require a constant supply of energy. Most adults need food intake to support their activities (dispersal, reproduction). Flight in particular, is a very energy-intensive activity, requiring rapid mobilization of energy sources, transport, and transformation of food energy into ATP. Those metabolic reactions are directly involved in mobilizing stored energy reserves and in releasing that energy for flight (Chapman, 1971). Quantitative assays of protein in the haemolymph and reproductive organs are of considerable importance for the understanding of the different physiological process associated with reproduction. In insects, changes in proteins are prominent during stages undergoing marked development and tissues differentiation such as during metamorphosis (Bakr et al. 2007). The reduction of the protein levels may be due to the destructive effect of the tested compounds on some of the cerebral neurosecretory cells of the brain of the treated nymphs (Engelmann, 1970).

In this study, The levels of haemolymph protein content were significantly decreased after 2, 4 and 6 days comparing with control nymphs.

The findings are in agreement with the reduction of protein in the haemolymph of the last two nymphal instar of Locusta migratoria when studied the effect of juvenile hormone and ecdysteroids on protein (Baehr, et al. 1979). The haemolymph protein content in late-aged last instar nymphs of 
S. gregaria was suppressed by the juvenoids (fenoxycarb) (El-Gammal et al. 1989). Also, the reduction of protein level in the haemolymph of the treated females and males of the last nymphal instars of $S$. gregaria was recorded by Badawy and El-Gammal (2000) when treated the $5^{\text {th }}$ female and male nymphal instars by benzoyal-phenyl urea (S-71624). Bakr, et al. (2009) found that when haemolymph samples were collected from untreated and treated nymphs, showed quantitative differences in protein content. During one day old treatment, the haemolymph protein levels significantly decreased in treated female nymphs after $24 \mathrm{hrs}$ of treatment, at different concentrations; 50, 75 and $100 \mathrm{ppm}$, of consult compared with untreated females. Also, haemolymph protein levels decreased in treated females after $168 \mathrm{hrs}$ of treatment. Also showed that, the protein content of ovaries and testes were significantly decreased in treated adult females and males of the treated $5^{\text {th }}$ nymphal instar during one and six day old when increasing Consult concentrations. Mahdy, (2010) revealed that Consult caused inhibition effect on total protein in nymphs and adults.

The decline in protein content obtained by consult can be explained according to Mitlin et al. (1977) who said that the inhibition of protein synthesis as a result of inhibition of DNA and RNA synthesis as the first sign of cell death. Also attributed this reduction to the inhibitory role of the tested IGRs on tissue protein synthesis. Also Bakr et al., (2007) reported that the reduction of protein level might be due to the destructive effect of consult on some of the cerebral neurosecrotory cells of the brain responsible for secretion of the proteins of the treated nymphs of $S$. gregaria. It is worthy to know that protein presented in all viable cells is essential to the process of cell division control of many chemical reactions in the metabolism of cells.

\section{Determination of total lipids:}

Immature stages of some insect groups need poly unsaturated fatty acids for normal development. Some groups (Lepidoptera, Orthoptera, and some others) use burn lipids (fatty acids) as flight fuels, which release large amounts of energy per unit weight of the substrate metabolized. The ability to rapidly mobilize and transport lipids from the fat body and the availability of oxygen from the tracheal system are major adaptations in those insects to burn fatty acids for flight. Some insects that metabolize lipids are able to fly continuously for hours and undertake long distance migration (Chapman, 1971).

In our results were found significant differences of total lipid contents at all treatments comparing with control. The mixture show highly significant decrease in the total lipid content, $4.57,4.04$ and $3.57 \mathrm{mg} / \mathrm{ml}$ haemolymph after 48,96 and $144 \mathrm{hrs}$ of treatment respectively, compared to control 7.3, 7.4 and $6.95 \mathrm{mg} / \mathrm{ml}$ haemolymph.

These results are in line with Hamadah et al., (2012) who found that the metabolic effects of pyriproxyfen, tebufenozide or lufenuron on the lipid content in two different tissues: hemolymph and fat body of the early-, midand late-aged old nymphs as well as one and four day old adult females. Hemolymph lipid content of the early-aged nymphs had been subjected to a reducing effect after treatment with high concentration of insect growth regulators (IGRs). With the age of nymphs, all IGRs could significantly or 
non-significantly reduce the lipid content of hemolymph. Concerning the lipid content in fat bodies of nymphs, a predominant inhibitory effect of all IGRs was detected. With regard to the adults, nymph treatments led to remarkable or slight decrease lipid content in the haemolymph. Also Abdel- Fattah et al. (2013) showed that treatment $5^{\text {th }}$ nymphal instar of $S$. gregaria with mixture of (entomopathogenic, Metarhizium anisopliae and growth inhibitor, Consult) causing decrease in lipid contents than that of control.

Injection of $0.1 \mu \mathrm{mol}$ of the synthetic adipokinetic hormone (PeramAKH II) onto the American cockroach Periplaneta Americana led to a significant reduction of the levels of neutral lipids and phospholipids in Haemolymph (Michitsch and Steele, 2008).

\section{Determination of cholesterol levels}

Insects can not synthesize sterols and thus immature insects need sterols as precursor that can be transformed into the molting hormone, which has a sterol structure. Eggs also contain sterols and the first instar may be able to molt without a dietary source, but subsequent molts may be impossible if dietary sterol is not present. Some adult insects need sterol to produce the normal number and/or hatching of eggs. The cholesterol is the biosynthesis precursor of ecdysone hormone in insects so, the estimation of the Juvenile hormone mimic role on this metabolite deemed necessary to evaluate its action upon the precursor of molting hormone (ecdysone) in $S$. gregaria (Rees, 1985).

our results showed that Treatment nymphs of the desert locust, $S$. gregaria with19ppm, 123ppm and (9ppm+50ppm) of Spinosad, consult and their mixture respectively, caused significant differences between treated and untreated nymphs during $2^{\text {nd }}, 4^{\text {th }}$ and $6^{\text {th }}$ days of application. Cholesterol contents were declined in all treatments. Highly significant decline were recorded in cholesterol content at nymphs treated with mixture.

These results are in agreement with Mettaweh et al. (2001a) who found that total cholesterols in the haemolymph of treated-grasshopper, Eurpepocnemis plorans plorans $\left(5^{\text {th }}\right.$ instar nymphs $)$ with the entomopathogenic fungus, $M$. flavovride $\left(5 \times 10^{6} \mathrm{spores} / \mathrm{ml}\right)$ decreased than the untreated ones. Also Abdel- Fattah et al. (2013) showed that treatment $5^{\text {th }}$ nymphal instar of $S$. gregaria with mixture of (entomopathogenic, Metarhizium anisopliae and growth inhibitor, Consult) causing decrease in contents than that of control.

\section{REFERENCES}

Abdel-Fattah, T. A; El-Dydamony, M. K.; Farag, A. A. and Abdel-Ghany, T. M. (2013). A new integrated strategy for controlling the desert locust, Schistocerca gregaria (Forskal). Egyptian Journal of Agricultural Research, 91(1): 95-110.

Alomenu, H. S. (1998). Current trend in African migratory locust plague prevention. Outlook on Agriculture, 14: 165-173. 
Badawy, N. S. and El-Gammal, A. M. (2000). The biochemical effects of the antichitin synthesis compound (S-71624) in the haemolymph of the fifth nymphal instar of Schistocerca gregaria (Forskal). Egyptain Journal of Applied Science, 15(9): 279-290.

Baehr, J. C.; Prochereon, P.; Papillion, M. and Dry, F. (1979): Haemolymph levels of juvenile hormone, ecdysteroids and protein during the last two larval instars of Locusta migratoria. J. Insect Physiol., 25: 415-421.

Bakr R. F. A.; Abdel- Fattah H. M. and Mohamed E. K. (2007). Effect of chitin synthesis inhibitor, Lufenuron on the development, haemolymph and antennal sensilla of Schistocerca gregaria (Forskal) (Orthoptera: Acrididae). African Journal of Biological science, 3(2): 35 - 43.

Bakr, R. F.; Mohammed, M. I.; El-Gammal, A. M. and Mahdy, N. M. (2009). Biological effects of Chitin-synthesis inhibitor, Hexaflumuron compound on the desert locust, Schistocerca gregaria (Forskal). Egyptian Academy Journal of biological Science, 1 (1): $49-57$.

Bradford, M. (1976). Rapid and sensitive method for the quantification of microgram quantities of proteins utilizing the principle of protein dye binding. Annual Biochemistry, 72: 248-254.

Chapman, R. F. (1971). The insects structure and Function. 4th ed. Cambridge: Cambridge University Press, 116-118 p.

El-Gammal, A.M.; Zohny, M.S.; Taha, G.Z.; Abdel-Hamid, M. (1989). The metabolic effect of the insect growth regulator, fenoxycarb, on Schistocerca gregaria last nymphal instar. Agricultural Research Review of Egypt, 67 (1): 125-132.

El-Gawhary, H. M. A. (1997). Biochemical Effect of Some Insect Growth Regulators. M. Sc. Thesis, Faculty of Agriculture, Cairo University, Egypt, $160 \mathrm{pp}$.

El- Sheikh, T. A. (2012). Biological, biochemical and histological effects of spinosad, Bacillus thuringiensis var. kurstaki and cypermethrin on the Cotton leafworm, Spodoptera littoralis (Boisd.). Egyptian Academy Journal of biological Science, 4 (1): 113-124.

Engelmann, F. (1970). The physiology of insect reproduction. Department of Zoology, California Univ., Los Angeles, Oxfod, Engl. Pergamon, 307pp.

Garriga, M. and Caballero, J. (2011) Insigths into the structure of urea-like compounds as inhibitors of the juvenile hormone epoxide hydrolase (JHEH) of the tobacco hornworm Manduca sexta: Analysis of the binding modes and structure-activity relationships of the inhibitors by docking and CoMFA calculations. Chemosphere 82, 1604-1613.

Hamadah, Kh. Sh.; Ghoneim, K. S. and Tanani, M. A .(2012). Effect of certain insect growth regulators on the lipid content of some tissues of the desert locust Schistocerca gregaria. Afr. J. Biochem. Res., 2012; 6(9): 121-128. 
Hamadah, Kh. Sh.; Ghoneim, K. S.; El-Hela, A. A.; Amer, S. M. and Mohammad, A. A. (2013). Disturbed Survival, Growth and Development of the Desert Locust Schistocerca gregaria by Different Extracts of Azadirachta indica (Meliaceae) and Nigella sativa (Ranunculaceae). Egyptian Academic Journal Biological Science, 6(2): $1-21$.

Knight, J. A.; Anderson, S. and Rawle, J. M. (1972). Chemical basis of the sulfo-phospho-vanillin reaction for estimating total serum lipids. Clinic Chemistry, 18: 199-202.

Lovejoy, N. R.; Mullen, S. P.; Sword, G. A.; Chapman, R. F. and Harrison, R. G. (2006). Ancient trans-Atlantic flight explains locust biogeography: molecular phylogenetics of Schistocerca. Protect Research Society B, 273: 767-774.

Mahdy, N. M. E. (2010). Physiological and histopathological aberrations induced by different insecticidal agents on the desert locust, Schistocerca gregaria (Forskal). Ph.D. Thesis, Faculty of science, Ain Shams University, 192pp

Matteson, P. C. (1992). A review of field studies of the environment. Impacts of locust and grasshopper control programs in Africa, European Journal of Cell Biology, 65: 347-355.

Mettaweh, H. H.; Gomma, E. A. A.; Sherif, R. M. and Abdel- Fattah, T. A. (2001). Biochemical changes of the haemolymph of the fifth nymphal instar of the grasshopper, Euprocnemis plorans plorans after infection with three entomopathogenic fungi. Egyptian Journal of Biochemical Pest Control, 11(2): 177-182.

Michitsch J, Steele JE. (2008). Carbohydrate and lipid metabolism in cockroach (Periplaneta americana) fat body are both activated by low and similar concentrations of peram-AKH II. Peptides 29: 226 -234.

Mitlin, N.; Wiygul, G. and Haynes, J. W. (1977). Inhibition of DNA synthesis in boll weevil (Anthonomus grandis Boheman) sterilized by Dimilin. Pestic. Biochem. Physiol., 7: 559-563.

Rees, H. H. (1985). Biosynthesis of ecdysone. In Comprehensive Insect Physiology, Biochemistry and Pharmacology, Pergam on press, Oxford, UK, pp 249-294.

Richmond, W. (1973). Preparation and properties of cholesterol oxidase from Nocardia sp. and its application to the enzymatic assay of total cholesterol in serum. Clinic Chemistry, 19: 1350-1356.

Ritchie, J. M. and Dobason, H. (1995). Desert locust control operations and their environmental impact. Natural Resource Institute Bullent, 67: 3642.

Robert, M. O.; Andrena, K.; Goettel, M. S.; Jacques, B. and Micheal, J. B. (2002). Attenuation of fungal infection in thermoregulating Locusta migratoria is accompanied by changes in haemolymph proteins. Journal of Invertebrate Pathology, 81: 19-24.

SAS Institute (1988). SAS/STAT User's Guide, Ver. 6.03. SAS Institute Inc., Cary, North Carolina. 
Thabit, A.; El Salamouny, S.; Abdel-Aal, A. E.; El-Sheikh, M. A. K. and Elnagar, S. (2010). Enhancement of Spodoptera littoralis suscebtability to nucleopolyhedrovirus (splimnpv) combined with insect growth regulators (IGRs) .Bull. Fac. Agric., Cairo Univ., 61: 92-96.

التغيـرات البيوكيميائيـة لمثبط تكـوين الكيتـين, الكونصـلت والسبينوســاد ونـاتج

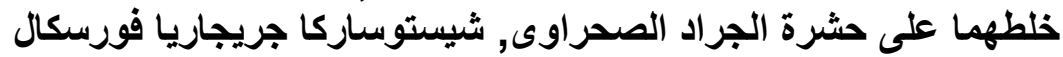

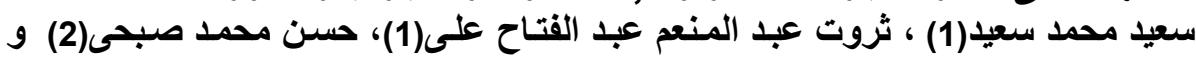

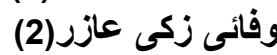

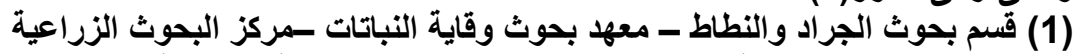

(2) قسم الموارد الحيوانية ـ معهد البحوث والدراسات الافريقية ـ جامعة القاهرة

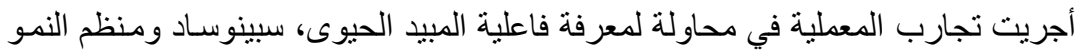

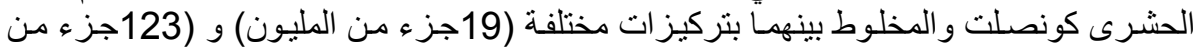

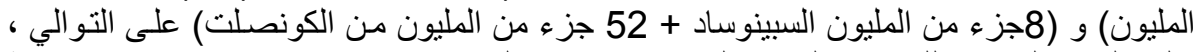

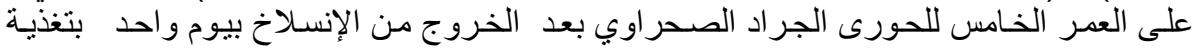
الحشر ات على الغذاء المعامل بالمركبات سابقة الذكر.

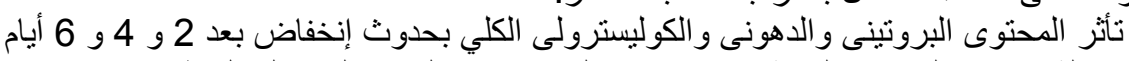

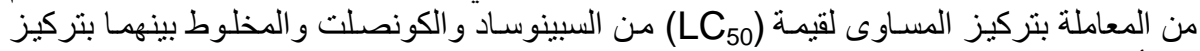

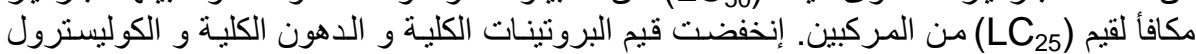

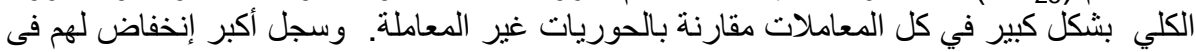

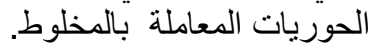

كلية الزراعة - جامعة المنصورة

كلية الزراعة - جامعة المنصورة

قام بتحكيم البحث

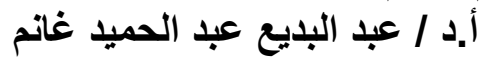

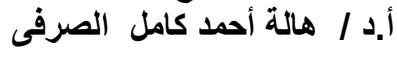

